\title{
Can Physical exercise be a priming adjuvant before vaccination? Insights from serological responses and severity of re-infection and reactogenicity of vaccines
}

Antoine AbdelMassih ( $\square$ antoine.abdelmassih@kasralainy.edu.eg )

Cairo University

Rahma Menshawey

Cairo University

Rafeef Hozaien

Cairo University

Aya Kamel

Cairo University

Fady Mishriky

Cairo University

Lauren Nathan

Cairo University

Elaria Yacoub

Cairo University

Aia Mohamed Hanoura

Cairo University

Nada AlShehry

Cairo University

Esraa Menshawey

Cairo University

Nadine El-Husseiny

Cairo University

\section{Reem Yasser}

Padova University

Mariem Arsanyous

Cairo University

Reem J. Husseiny

Cairo University

Mahmoud Seyam

Cairo University

Doaa Massoud

Cairo University

Nada Ali

Cairo University

Assem Kassim

Cairo University 
Mostafa AmanAllah

Cairo University

Rokaya Elsayed

Cairo University

Hesham Sheashaa

Cairo University

Yousef Husseiny

New Giza University

Nourhan Hassan

Cairo University

Kirollos Badr

Cairo University

Amr Elkhateb

Cairo University

Verina Fouad

Cairo University

Mayada Elfishawy

Cairo University

Omar Medhat

Cairo University

Mai Mustafa

Cairo University

Noha Khalil

Cairo University

Rawan Elsayed

Cairo University

Youssef Nada

Cairo University

Passant Elshawarbi

Cairo University

Noha Abdelmoneim

Cairo University

Nada Hassan

Cairo University

Mariam Messiha

Cairo University

Marihan Ghazy

Cairo University

Emmy Abdelfatah

Cairo University

Febronia Nasry

Cairo University

Ramy Gayed

Cairo University

Marian Eesa 
Cairo University

\section{Merna Luis}

Alexandria University

Estfana Eskandar

Cairo University

Shenoda Yacoub

Cairo University

Maram Rajab

Cairo University

Mariam Abdelaziz

Cairo University

Nadine Elgamal

Cairo University

Hutaf Jaber

Cairo University

Sara Tayssir

Cairo University

Mark Michael

Cairo University

Ahmed Sabry

Cairo University

Joseph Shehata

Cairo University

Rania Abdelaziz

Cairo University

Sherry Rateb

Cairo University

Ahmed El-Maghraby

Cairo University

Yara Mahjoub

Cairo University

Alaa Amr

Cairo University

Amin Amin

Cairo University

Peter Kelada

Cairo University

Alaa Saud

Cairo University

Shahd Ragab

Cairo University

Basant Eltaher

Ain Shams University

Rahma Hassan Galal

Cairo University 


\section{Omnya Mahmoud Aly}

Cairo University

\section{Taquwa Aly}

Cairo University

\section{Rana AbdelHaleem}

Cairo University

Areeg ElShaarawy

Cairo University

Omnia Mohamed

Cairo University

\section{Systematic Review}

Keywords: Physical exercise, COVID-19 vaccine, Re-infection, immunogenicity, reactogenicity

Posted Date: November 16th, 2020

DOI: https://doi.org/10.21203/rs.3.rs-108776/v1

License: (c) This work is licensed under a Creative Commons Attribution 4.0 International License. Read Full License 


\section{Abstract}

Background: As more than 37 million confirmed cases and 1 million deaths worldwide from COVID-19, we flied to think about supporting immunity, So, there are more than 150 coronavirus vaccines and clinical trials are being developed. The success of those vaccines depends mainly on immunologic memory. People who are at high risk of re-infection with COVID-19 don't show any evidence of having B-cell memory. 10-20\% of infected patients don't develop antibody response. randomized controlled trials and cross-sectional studies proved variant results about the effect of chronic exercise on vaccination function.

The aim of this review is to suggest that exercise is an important adjuvant strategy for prevention of re-infection and for development of better protective responses following vaccination.

Methods: Embase, Medline and the Cochrane Central Register were used to search for specific keywords such as "COVID-19" OR "SARS-CoV-2" AND "Re-infection" for relevant publications up to $1^{\text {st }}$ of Nov. 2020. The systematic review was performed using PRISMA protocol.

Results: According to inclusion criteria, 6 case reports from search and one case from a press conference were identified. The average age of re-infected patients was 36 years. The average intervening period between initial infection and reinfection was 105 days. 75\% of cases who have been tested for antibodies after $1^{\text {st }}$ infection were negative, and turned seropositive after second infection. $57 \%$ of cases developing re-infection had worse clinical manifestation.

Conclusion: Regular moderate intensity exercise not only can enhance the secondary antibody response of B cell memory but also decrease the severity of re-infection and the adverse reactogenicity of potential vaccines under development.

\section{Background}

The COVID-19 pandemic is a critical moment in the 21th century. Statistics recorded more than 1 million deaths and more than 54 million confirmed cases worldwide (1)

Concerning this global health emergency that is threatening many lives, Vaccine developers started working out trying to bring a vaccine to the market in a record time to alleviate the global crisis. (2)

Owing to the urgent need to the vaccine, some developers are running the trial phases simultaneously with the clinical process for SARS-CoV-2. Hopefully more than 150 coronavirus vaccines are under development across the world. Hard efforts are being exerted to make finding such a vaccine possible, including the U.S.(3)

Although the current vaccines under development offer great hopes, there is a major concern about the success of these vaccines in providing the desired protective immunity against infection.

Liao and colleagues didn't only explain the uncontrollable activation of immune system and its damaging effect on the lung milieu in severe COVID-19 patients but they also pointed out that there's no evidence in the early recovery period of $B$ cell memory in the patients with the worst and the most serious outcomes. Therefore, they are more prone to be reinfected with COVID-19 and less likely to develop humoral immunity via antibodies by any possibly made vaccine. (4)

According to Wu and Long et al series, this finding goes in agreement with that $10-20 \%$ of infected patients fail to develop antibody responses. On account of the rapid decline of their immune responses 16 days after initial infection, these patients are left at risk of reinfection. That's why the most important factor in predicting the success of any upcoming vaccine is the power of the generated immunologic memory after being infected. $(5,6)$

Page 5/11 
Studies show effect of exercise on the immune response after vaccination. Comparing both physically active candidates and those of sedentary life styles in a cross-sectional study, the antibody responses to vaccines are greater in older adults exercising regularly. Another study compares cardiovascular and flexibility trainings for 10 months in previously non-active participants. According to Woods et al., it is shown that cardiovascular exercise done about an hour 3 times each week, leads to increase in neuroprotection evaluated at 6 months after influenza vaccination. Moreover, chronic exercise improves the immune responses to new antigens.(7)

The aim of this article is to report all the re-infection cases, and their characteristics and to explain the pathophysiologic mechanisms involved in improvement of immunologic memory in the elderly with exercise. This might render exercise an important adjuvant strategy for prevention of re-infection and for development of better protective responses following vaccination.

\section{Methodology}

This systematic review has been conducted in agreement with the guidelines of the PRISMA Statement (Preferred Reporting Items for Systematic Reviews and Meta-Analysis). ${ }^{13}$

\section{>Data Search}

A computer run has been performed on EMBASE, Medline and the Cochrane Central Register (From $1^{\text {st }}$ November 2019 to $1^{\text {st }}$ of November 2020). The following terms were included in the search: "COVID-19" OR "SARS-CoV-2" (Severe Acute Respiratory syndrome Coronaviridae 2) AND "Re-infection"

\section{>Study Selection criteria}

Population: No specific age group or sex

Intervention: COVID-19

Comparison: No comparison has been a purpose of the study

Outcome: Re-infection by COVID-19

Observational epidemiological studies and case reports addressing the re-infection with COVID-19 have been considered eligible.

\section{Results}

Literature search has identified 6 cases reported of being re-infected with COVID-19. A seventh case was identified from Melbourne Australia from a press conference of Daniel Andrews, Victoria's premier. (8-13)

Results show that $75 \%$ of cases who have been tested for antibodies after first infection $(n=4)$ were negative, and turned seropositive after second infection. (Table 1, Figure 1)

Results also show that $57 \%$ of cases developing re-infection had worse clinical manifestations, and required hospitalization despite mild or asymptomatic first infection (Table 1, Figure 2)

The average intervening period between initial infection and re-infection was 105 days, and the average age of reinfected patients was 36 years. 
Data from those reports were scarce, reporting no details about comorbidities or body mass index of re-infected cases

\section{Discussion}

An under trial COVID-19 vaccine, analyzed by Sahin and colleagues, showed evident development of neutralizing antibodies and CD-8 response. However, the mRNA vaccine-induced B-cell response reached its highest two weeks after immunization and then declined afterwards.(14)

The effect of SARS-COV-2 vaccine on the body's immune response was analyzed subsequent to the administration of two doses; the viral-induced antibody concentration seemed to diminish typically around day 43. This finding was in concordance with the results that Wu and Long et al have illustrated in response to the infection, thus clearly providing evidence of the feeble B-cell response to infection as well as vaccination. $(5,6)$

The memory B cells produced during the primary immune response are specific to the antigen involved during the first exposure; in a secondary response, the memory B cells specific to the antigen or similar antigens will respond. When memory B cells reencounter their specific antigen, they proliferate and differentiate into plasma cells, which then respond to and clear the antigen; such clearance is achieved by what is called the secondary antibody response. It is regarded that that secondary antibody response is the most crucial event that can prevent re-infection with a certain pathogen.(15)

In this context, Kapasi and colleagues tested the secondary antibody response reflective of B cell memory in old vs. young mice in response to bouts of exercise. Secondary antibody response appeared to be exercise dependent, because old mice that received 1 bout of intense exercise demonstrated increased anti-antibody levels compared with old nonexercising mice. Moreover, the old mice that received the booster immunization after undergoing 1 bout of intense exercise, have attained levels of anti-HSA antibodies comparable to those seen in the young mice. In accordance with our findings, Long and colleagues have tested the vaccine responses of two groups of old aged individuals. They have succeeded in showing that antibodies in response to pneumococcal vaccine improved significantly following regular moderate intensity exercise.(16)

Such findings signify that exercise has the ability to not only improve the outcome of infected cases but to prevent reinfection and can improve the response of vaccinated individuals. This should be taken into account during the ongoing trials for a potential COVID-19 vaccine.

Another important concern, during development of the vaccine is the severity of re-infection when compared to the initial infection. As shown in Table 1 as well as Figure 2 that $>50 \%$ of reported re-infected cases are showing a more severe spectrum of the disease. This should be viewed with extreme caution in conjunction with Sahin et al findings of augmented systemic adverse reactogenicity after the second dose. Reactogenicity is the series of adverse local or systemic reactions after vaccination. It is usually correlated with baseline serum levels of IL-6. (17)

In spite of reduced vaccine immunogenicity in old age due to insufficient B-cell memory, a number of studies, particularly those of Cowling and associates, illustrated that the local and, to a lesser extent, the systemic reactogenicity of vaccines increased in older adults. This finding could be attributed to the reduction of Soleus Muscle Protein SOCSP3 due to lack of exercise and sedentary lifestyle, noting that SOCSP3 acts to repurpose IL-6 from a pure pro-inflammatory to a rather regulatory cytokine role.(18)

Thus, exercise not only can improve the immunogenicity of a potential vaccine but can also decrease the severity of reinfection and the adverse reactogenicity of potential vaccines under development. 


\section{Conclusion}

In conclusion, we found that not only was exercise important for the overall outcome of an infected patient but also crucial to a healthy memory B cell response. This is especially important after more than half of the documented cases of re-infection were found to have worse clinical manifestations than in their first infection. This raises the possibility that regular cardiovascular exercise might be pivotal for both a stronger immune response and the prevention of a reinfection all together. Exercise might be beneficial as well in preventing the reactogenicity of the potential vaccines under development.

Figure 3 summarizes how regular physical exercise can improve outcome of potential COVID-19 vaccination

\section{Declarations}

\section{Conflict of interest:}

None

\section{References}

1. WHO. COVID-19 COVID-19. WHO J covid 19, Reg Situational Updat Africa. 2020;

2. WHO Covid-19. Draft landscape of COVID-19 candidate vaccines. Who. 2020;

3. Lurie N, Saville M, Hatchett R, Halton J. Developing Covid-19 Vaccines at Pandemic Speed. N Engl J Med. 2020;

4. Liao M, Liu Y, Yuan J, Wen Y, Xu G, Zhao J, Cheng L, Li J, Wang X, Wang F, Liu L, Amit I, Zhang S, Zhang Z. Singlecell landscape of bronchoalveolar immune cells in patients with COVID-19. Nat Med [Internet]. 2020;26(6):842-4. Available from: http://dx.doi.org/10.1038/s41591-020-0901-9

5. Long Q-X, Tang X-J, Shi Q-L, Li Q, Deng H-J, Yuan J, Hu J-L, Xu W, Zhang Y, Lv F-J, Su K, Zhang F, Gong J, Wu B, Liu X-M, Li J-J, Qiu J-F, Chen J, Huang A-L. Clinical and immunological assessment of asymptomatic SARS-CoV-2 infections. Nat Med [Internet]. 2020 Aug 18;26(8):1200-4. Available from: http://www.nature.com/articles/s41591020-0965-6

6. Compeer EB, Uhl LFK. Antibody response to SARS-CoV-2 - sustained after all? Nat Rev Immunol [Internet]. 2020 Oct 11;20(10):590-590. Available from: http://www.nature.com/articles/s41577-020-00423-9

7. Woods JA, Keylock KT, Lowder T, Vieira VJ, Zelkovich W, Dumich S, Colantuano K, Lyons K, Leifheit K, Cook M, Chapman-Novakofski K, McAuley E. Cardiovascular exercise training extends influenza vaccine seroprotection in sedentary older adults: The immune function intervention trial. J Am Geriatr Soc. 2009;57(12):2183-91.

8. No Title [Internet]. Available from: https://www.theguardian.com/world/2020/oct/21/australia-may-have-recordedfirst-case-of-covid-19-re-infection

9. Nachmias V, Fusman R, Mann S, Koren G. The first case of documented Covid-19 reinfection in Israel. IDCases [Internet]. 2020;22:e00970. Available from: https://linkinghub.elsevier.com/retrieve/pii/S221425092030278X

10. Tillett RL, Sevinsky JR, Hartley PD, Kerwin H, Crawford N, Gorzalski A, Laverdure C, Verma SC, Rossetto CC, Jackson D, Farrell MJ, Van Hooser S, Pandori M. Genomic evidence for reinfection with SARS-CoV-2: a case study. Lancet Infect Dis [Internet]. 2020 Oct; Available from: https://linkinghub.elsevier.com/retrieve/pii/S1473309920307647

11. To KK-W, Hung IF-N, Ip JD, Chu AW-H, Chan W-M, Tam AR, Fong CH-Y, Yuan S, Tsoi H-W, Ng AC-K, Lee LL-Y, Wan P, Tso EY-K, To W-K, Tsang DN-C, Chan K-H, Huang J-D, Kok K-H, Cheng VC-C, Yuen K-Y. Coronavirus Disease 2019 (COVID-19) Re-infection by a Phylogenetically Distinct Severe Acute Respiratory Syndrome Coronavirus 2 Strain 
Confirmed by Whole Genome Sequencing. Clin Infect Dis [Internet]. 2020 Aug 25; Available from:

https://academic.oup.com/cid/advance-article/doi/10.1093/cid/ciaa1275/5897019

12. Van Elslande J, Vermeersch P, Vandervoort K, Wawina-Bokalanga T, Vanmechelen B, Wollants E, Laenen L, André E, Van Ranst M, Lagrou K, Maes P. Symptomatic SARS-CoV-2 reinfection by a phylogenetically distinct strain. Clin Infect Dis [Internet]. 2020 Sep 5; Available from: https://academic.oup.com/cid/advancearticle/doi/10.1093/cid/ciaa1330/5901661

13. Prado-Vivar B, Becerra-Wong M, Guadalupe JJ, Marquez S, Gutierrez B, Rojas-Silva P, Grunauer M, Trueba G, Barragan V, Cardenas P. COVID-19 Re-Infection by a Phylogenetically Distinct SARS-CoV-2 Variant, First Confirmed Event in South America. SSRN Electron J [Internet]. 2020; Available from: https://www.ssrn.com/abstract=3686174

14. Sahin U, Muik A, Derhovanessian E, Vogler I, Kranz LM, Vormehr M, Baum A, Pascal K, Quandt J, Maurus D, Brachtendorf S, Lörks V, Sikorski J, Hilker R, Becker D, Eller A-K, Grützner J, Boesler C, Rosenbaum C, Kühnle M-C, Luxemburger U, Kemmer-Brück A, Langer D, Bexon M, Bolte S, Karikó K, Palanche T, Fischer B, Schultz A, Shi P-Y, Fontes-Garfias C, Perez JL, Swanson KA, Loschko J, Scully IL, Cutler M, Kalina W, Kyratsous CA, Cooper D, Dormitzer PR, Jansen KU, Türeci Ö. COVID-19 vaccine BNT162b1 elicits human antibody and TH1 T cell responses. Nature [Internet]. 2020 Oct 22;586(7830):594-9. Available from: http://www.nature.com/articles/s41586-020-2814-7

15. Ahlstedt S, Holmgren J, Hanson LA. The primary and secondary antibody response to Escherichia coli 06 lipopolysaccharide analysed at the humoral and cellular level. Amount and avidity of the antibodies in relation to protective capacity. Immunology [Internet]. 1973 Feb;24(2):191-202. Available from:

http://www.ncbi.nlm.nih.gov/pubmed/4571425

16. Kapasi ZF, Catlin PA, Joyner DR, Lewis ML, Schwartz AL, Townsend EL. The effects of intense physical exercise on secondary antibody response in young and old mice. Phys Ther. 2000;

17. Hervé C, Laupèze B, Del Giudice G, Didierlaurent AM, Tavares Da Silva F. The how's and what's of vaccine reactogenicity. npj Vaccines [Internet]. 2019 Dec 24;4(1):39. Available from:

http://www.nature.com/articles/s41541-019-0132-6

18. Pattamaprapanont P, Muanprasat C, Soodvilai S, Srimaroeng C, Chatsudthipong V. Effect of Exercise Training on Signaling of Interleukin-6 in Skeletal Muscles of Type 2 Diabetic Rats. Rev Diabet Stud [Internet]. 2016;13(23):197-206. Available from: http://www.soc-

bdr.org/content/e4/e887/volRdsVolumes17236/issRdslssues18244/chpRdsChapters18275/strRdsArticles18304/? preview=preview

\section{Table}

Table 1: Reported Cases of Re-infection from COVID-19 


\begin{tabular}{|c|c|c|c|c|c|c|c|}
\hline $\begin{array}{l}\text { Country } \\
\text { of origin }\end{array}$ & $\begin{array}{l}\text { Age } \\
\text { (Years) }\end{array}$ & Sex & $\begin{array}{l}\text { Intervening } \\
\text { Period } \\
\text { (days) }\end{array}$ & $\begin{array}{l}\text { Antibodies } \\
\text { after first } \\
\text { infection }\end{array}$ & $\begin{array}{l}\text { Antibodies } \\
\text { after re-- } \\
\text { infection }\end{array}$ & $\begin{array}{l}\text { Manifestations } \\
\text { during first } \\
\text { infection }\end{array}$ & $\begin{array}{l}\text { Manifestations } \\
\text { during second } \\
\text { infection }\end{array}$ \\
\hline Israel & 20 & Male & 120 & $\mathrm{~N} / \mathrm{A}$ & $\mathrm{N} / \mathrm{A}$ & Mild & Asymptomatic \\
\hline Brazil & 36 & Female & 120 & Negative & $\begin{array}{l}\text { Positive (Ig } \\
\text { A and IgG) }\end{array}$ & Mild & Severe \\
\hline $\begin{array}{l}\text { Hong } \\
\text { Kong }\end{array}$ & 33 & Male & 142 & Negative & $\begin{array}{l}\text { Positive (Ig } \\
\text { G) }\end{array}$ & Mild & Asymptomatic \\
\hline USA & 25 & Male & 48 & Negative & $\begin{array}{l}\text { Positive (Ig } \\
\text { M and Ig } \\
\text { G) }\end{array}$ & Mild & Severe \\
\hline Ecuador & 46 & Male & 63 & $\begin{array}{l}\text { Positive (Ig } \\
\text { M) }\end{array}$ & $\begin{array}{l}\text { Positive (Ig } \\
\mathrm{M} \text { and } \mathrm{Ig} \\
\mathrm{G})\end{array}$ & Mild & Severe \\
\hline Belgium & 51 & Female & 93 & $\mathrm{~N} / \mathrm{A}$ & $\begin{array}{l}\text { Positive (Ig } \\
\text { G) }\end{array}$ & Mild & Mild \\
\hline Australia & 42 & Male & 150 & $\mathrm{~N} / \mathrm{A}$ & $\mathrm{N} / \mathrm{A}$ & Mild & Severe \\
\hline
\end{tabular}

Abbreviations: N/A: Non applicable

\section{Figures}

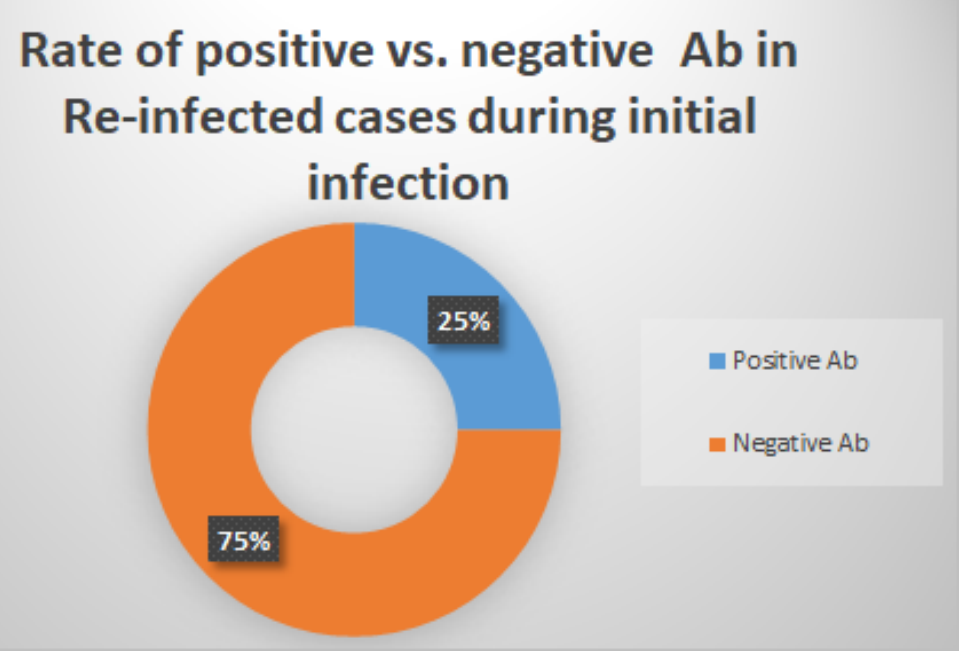

Figure 1

Rate of negative vs. positive antibody responses in re-infected cases after initial infection 


\section{Severity of re-infection in reported re-infected cases}

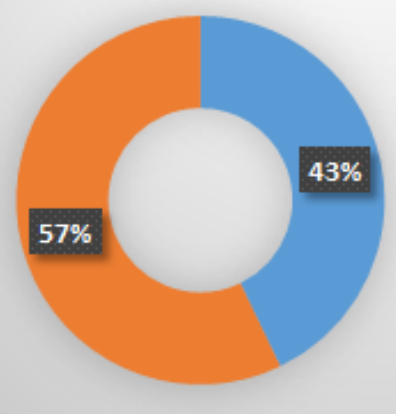

Mild Clinical Manifestations

More Sever e Clinical Spectrum

\section{Figure 2}

Summary of beneficial effects of regular physical exercise on immunogenicity and reactogenicity of a potential COVID19 vaccine
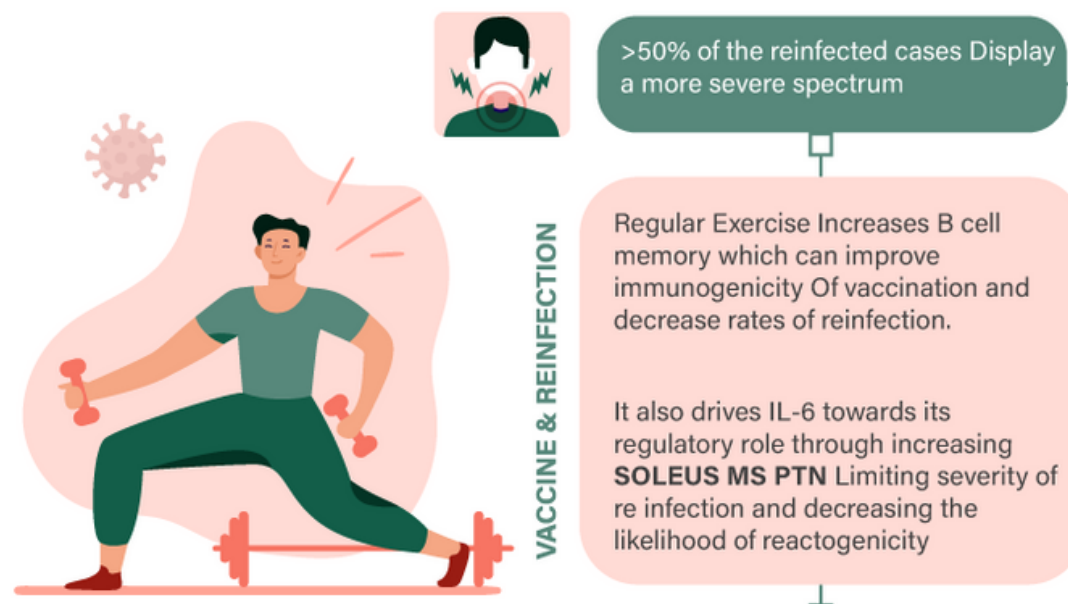

Regular Exercise Increases B cell memory which can improve immunogenicity Of vaccination and decrease rates of reinfection.

It also drives IL-6 towards its regulatory role through increasing SOLEUS MS PTN Limiting severity of re infection and decreasing the likelihood of reactogenicity
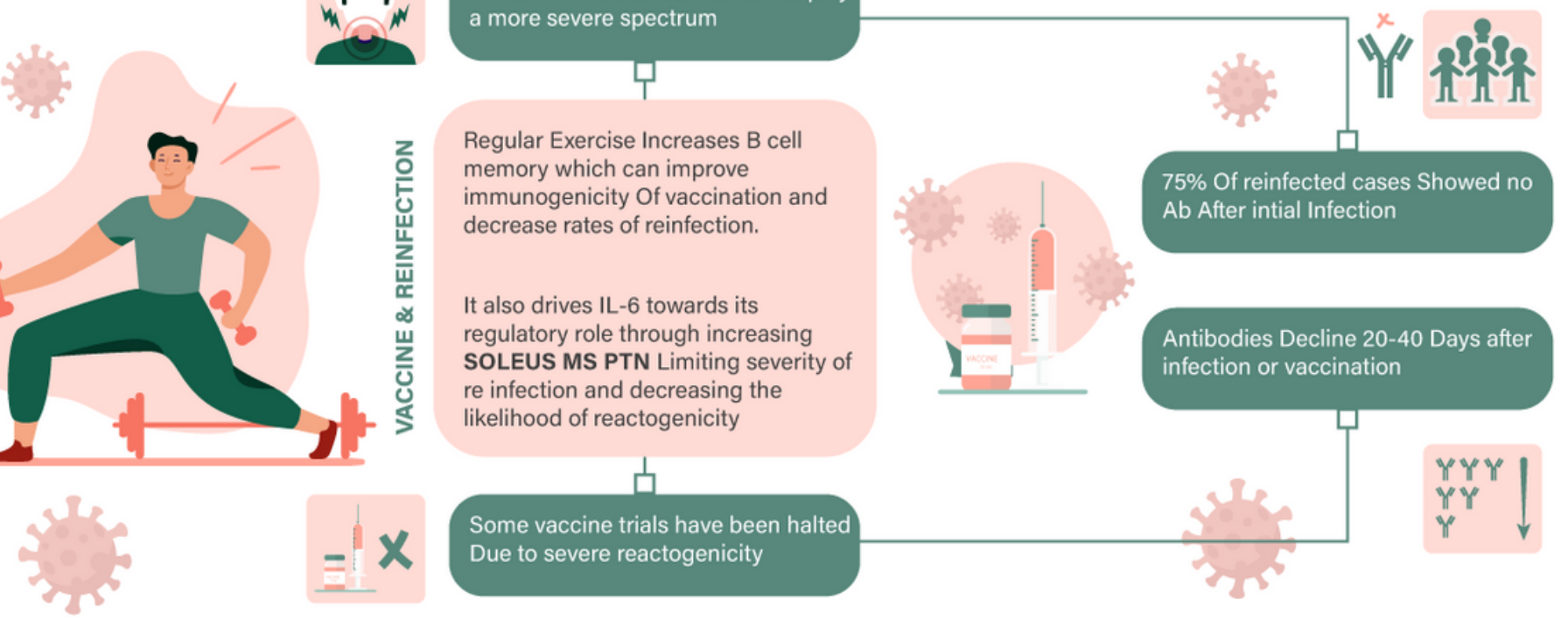

\section{Figure 3}

Summary of beneficial effects of regular physical exercise on immunogenicity and reactogenicity of a potential COVID19 vaccine 